Published in final edited form as:

Methods Mol Biol. 2012 ; 925: 49-59. doi:10.1007/978-1-62703-011-3_3.

\title{
Generation of Trophoblast Stem Cells
}

\author{
Michael C. Golding, PhD \\ Texas A\&M University, Department of Veterinary Physiology, Room 338 VMA - 4466 TAMU, \\ College Station Texas, 77845 \\ Michael C. Golding: mgolding@cvm.tamu.edu
}

\begin{abstract}
The isolation and culture of both embryonic and extraembryonic stem cells provide an enormous opportunity to study the molecular processes that establish and maintain lineage-specific, monoallelic patterns of gene expression. This chapter describes the isolation an culture of trophectoderm stem cells from mouse blastocyst stage embryos. Using this powerful in vitro system, scientists can now begin to tease apart the epigenetic processes that result in placental patterns of imprinted gene expression and begin to better understand the role these genes play in development and disease.
\end{abstract}

\section{Keywords}

Placental stem cell; Trophectoderm; Extraembryonic lineage; TS cell

\section{Introduction}

Genomic imprinting is a specialized transcriptional regulatory mechanism that restricts expression to the maternally or paternally inherited allele (1). Misregulation of these lineage-specific patterns of monoalleleic gene expression has been associated with numerous developmental disorders and cancer $(2,3)$. Recently, we have come to recognize the extreme importance of imprinted gene expression to the proper development and function of the placenta, through observed defects in the development of embryos produced through assisted reproductive technologies $(2,4-10)$.

To better define these and other molecular events driving mammalian embryogenesis, pluripotent stem cells from each of the three distinct lineages present within the preimplantation blastocyst have been derived (11-14). Embryonic (ES), trophectoderm (TS), and extraembryonic endoderm (XEN) stem cells each possess the developmental potential of their founding lineages and exhibit distinct patterns of imprinted X-inactivation and gene expression (14-17). However, the molecular basis for the establishment and maintenance of these differing monoallelic patterns of gene expression remains poorly defined.

Trophectoderm stem cells represent a powerful system with which to study the developmental origins of the extraembryonic tissues that give rise to the placenta (13). In the analysis of patterns of imprinted gene expression it is essential to be able to identify parentof-origin expression. To this end, genetic crosses between distinct strains of mice allow the 
tracking and identification of allele-specific patterns of gene expression through the identi fi cation of single-nucleotide polymorphisms either through direct sequencing or using restriction enzyme digestion (18). This chapter describes the derivation of TS cells from embryos potentially derived from these crosses.

\section{Materials}

\subsection{Production of Embryonic Feeders}

1. A source of mouse embryonic fi broblasts-either commercial or primary cultures.

2. DMEM with $10 \%$ Fetal Bovine Serum and $1 \%$ Antibiotic/Antimycotic.

3. Phosphate-buffered saline.

4. $0.1 \%(\mathrm{w} / \mathrm{v})$ trypsin-1 mM EDTA.

5. Mitomycin C.

6. DMSO.

7. T175 Flasks or $15 \mathrm{~cm}$ tissue culture dishes.

8. Freezing vials.

9. $-80{ }^{\circ} \mathrm{C}$ Freezer.

10. Liquid nitrogen tank or $-160{ }^{\circ} \mathrm{C}$ freezer.

11. $37^{\circ} \mathrm{C}$ Water bath.

\subsection{Derivation of Trophectoderm Stem Cells}

1. TS Cell Medium:

$500 \mathrm{ml}$ RPMI (Sigma).

$6 \mathrm{ml} \mathrm{Pen} / \mathrm{strep}$ (50 $\mu \mathrm{g} / \mathrm{ml}$ each fi nal concentration, Sigma).

$6 \mathrm{ml} 100 \mathrm{mM}$ sodium pyruvate (Invitrogen 11360070, final concentration 1 $\mathrm{mM})$.

$6 \mathrm{ml} 10 \mathrm{mM}$ B-mercaptoethanol (Sigma, final concentration $100 \mu \mathrm{M})(14.3 \mathrm{M}$ BME use $35 \mu \mathrm{l}$ in $50 \mathrm{ml}$ to make $100 \times$ stock). $1,000 \times$ FGF4 (R\&D Systems). 1,000× FGF Basic (R\&D Systems). $1,000 \times$ Heparin $(1 \mathrm{mg} / \mathrm{ml})$. $6 \mathrm{ml} 200 \mathrm{mM} \mathrm{L}$-glutamine (Sigma, fi nal concentration $2 \mathrm{mM}$ ). FCS to fi nal volume of 15\% (Hyclone ES Serum, Fisher Scientific).

2. Low-wall tissue culture dishes.

3. Mitomycin C-treated MEF feeders.

4. Source of Mouse blastocysts. 


\subsection{Culture of Trophectoderm Stem Cells in the Absence of Feeders}

1. Mitomycin C-treated MEFs.

2. DMEM/10\% FBS.

3. $15 \mathrm{~cm}$ Dishes.

4. TS medium.

5. $0.45 \mu \mathrm{m}$ Filter.

6. $10-15 \mathrm{ml}$ Syringe.

7. $37^{\circ} \mathrm{C}$ Water bath.

\subsection{Freezing TS Cell Cultures}

1. TS Cell Medium:

$500 \mathrm{ml}$ RPMI (Sigma).

$6 \mathrm{ml} \mathrm{Pen} / \mathrm{strep}$ (50 $\mu \mathrm{g} / \mathrm{ml}$ each final conc Sigma).

$6 \mathrm{ml} 100 \mathrm{mM}$ sodium pyruvate (Invitrogen, final concentration $1 \mathrm{mM}$ ).

$6 \mathrm{ml} 10 \mathrm{mM}$ B-mercaptoethanol (Sigma, final concentration $100 \mu \mathrm{M})(14.3 \mathrm{M}$

BME use $35 \mu \mathrm{l}$ in $50 \mathrm{ml}$ to make $100 \times$ stock).

$1,000 \times$ FGF4 (R\&D Systems).

1,000× FGF Basic (R\&D Systems).

$1,000 \times$ Heparin $(1 \mathrm{mg} / \mathrm{ml})$.

$6 \mathrm{ml} 200 \mathrm{mM}$ L-glutamine (Sigma, final conc $2 \mathrm{mM}$ ).

FCS to final volume of 15\% (Hyclone ES Serum Fisher Scientific).

2. Freezing Medium ( $50 \mathrm{ml}) .25 \mathrm{ml}$ FBS.

$25 \mathrm{ml}$ of TS cell Medium.

$5 \mathrm{ml}$ of DMSO.

3. Cryo-Vials.

4. $-80{ }^{\circ} \mathrm{C}$ Freezer.

5. $-160^{\circ} \mathrm{C}$ Freezer or Liquid Nitrogen.

6. Cell Freezer.

\section{Methods}

\subsection{Production of Embryonic Feeders: Mitomycin C Treatment of Mouse Embryonic Fibroblasts}

Trophectoderm Stem Cells require several soluble, secreted factors, including Activin and TGF-Beta, in order to maintain an undifferentiated state (19). Moreover, TS cell lines grown on MEF-feeder layers are easier to maintain than those grown in MEF-conditioned medium. 
Here we will describe the production of growth-arrested mouse embryonic fibroblasts to be used as feeder layers in the culture of trophectoderm stem cells. Using the powerful chemotherapeutic Mitomycin-C to irreversibly inhibit DNA replication, treated MEFs can be plated and although their growth has been arrested they still continue to secrete factors necessary for TS cell maintenance. It is best to prepare multiple vials of feeder cells at once to ensure uniformity.

1. Thaw a frozen vial of MEFs in a $37{ }^{\circ} \mathrm{C}$ water bath and transfer entire contents into a $1.5-\mathrm{ml}$ tube and centrifuge at $400 \times g$ for $4 \mathrm{~min}$.

2. Remove the supernatant and gently resuspend the cells in $1 \mathrm{ml}$ of DMEM/10\% FBS.

3. Split cells ( $500 \mu \mathrm{l}$ each) into two $15 \mathrm{~cm}$ dishes, each containing $25 \mathrm{ml}$ DMEM/10\% FBS.

4. Culture cells at $37^{\circ} \mathrm{C}$ for $3-4$ days or until cells reach $\sim 90 \%$ confluence. Do not let the cells become confluent.

5. Passage the cells by removing the growth medium and rinse twice with $10 \mathrm{ml}$ PBS per dish.

6. Add $2.5 \mathrm{ml} 0.1 \%$ trypsin to each dish and incubate for $\sim 2 \mathrm{~min}$ at $37^{\circ} \mathrm{C}$. Tap each dish to dissociate the cell monolayer.

7. Add $10 \mathrm{ml}$ of DMEM/10\% FBS to the dish and gently pipette to break cell aggregates.

8. Transfer cells to a $15 \mathrm{ml}$ tube and centrifuge at $200 \times g$ for $4 \mathrm{~min}$. Resuspend cell pellet in $15 \mathrm{ml}$ of DMEM/10\% FBS.

9. Split ( $3 \mathrm{ml}$ each) into fi ve new $15 \mathrm{~cm}$ plates containing $22 \mathrm{ml}$ DMEM/10\% FMS.

10. Culture cells at $37{ }^{\circ} \mathrm{C}$ for $3-4$ days or until cells reach $\sim 90 \%$ confluence. Do not let the cells become confluent.

Caution-Mitomycin C is extremely toxic. Please exercise caution when handling.

11 When cells are ready prepare $200 \mathrm{ml}$ of DMEM/10\%FBS containing $10 \mu \mathrm{g} / \mathrm{ml}$ Mitomycin-C. Typically this compound is sold in $2 \mathrm{mg}$ aliquots. Resuspend the entire contents of the vial in $4 \mathrm{ml}$ of DMEM/10\% FBS and add this to a final volume of $200 \mathrm{ml}$ of DMEM/10\% FBS. This will produce enough Mitomycin-C medium to treat ten $15 \mathrm{~cm}$ plates. Add Mitomycin-C medium and incubate cells for $2 \mathrm{~h}$ at $37^{\circ} \mathrm{C}$.

12 Remove the medium and rinse cells twice, with $20 \mathrm{ml}$ of PBS.

13 Add $5 \mathrm{ml}$ of Trypsin as described above and place in incubator for $\sim 2 \mathrm{~min}$.

14 Tap each dish to dissociate the cell monolayer. Add $10 \mathrm{ml}$ of DMEM/10\% FBS to the dish and gently pipette to break cell aggregates.

15 Transfer the cells from each plate into a $15 \mathrm{ml}$ tube and centrifuge at $200 \times g$ for 4 min. 
16 Resuspend cell pellet in $5 \mathrm{ml}$ of Freezing Medium-60\% FBS, 30\% DMEM, and $10 \%$ DMSO—and aliquot into freezing vials. Typically, one vial will contain enough cells to cover one $10 \mathrm{~cm}$ dish or two 12-well plates.

17 Place vials in the $-80{ }^{\circ} \mathrm{C}$ freezer overnight and transfer to liquid nitrogen or a $-160{ }^{\circ} \mathrm{C}$ freezer for long-term storage.

\subsection{Derivation of Trophectoderm Stem Cells}

TS Cells are derived by plating blastocyst stage embryos on an MEF-feeder layer and allowing outgrowths to form. When these outgrowths are dissociated, culture of the derivative cells in TS cell medium will promote the growth of trophectoderm and XEN stem cell colonies. These colonies can be picked and stable TS cell lines derived.

\subsubsection{Preparation for TS Cell Medium}

1. FGF Basic (R\&D Systems) and FGF4 (R\&D Systems) need to be suspended in 1 $\mathrm{ml}$ of PBS/0.1\% BSA (we use the NEB FBS that comes with Restriction Enzymes and filter sterilize) and make $50 \mu \mathrm{l}$ aliquots and freeze at $-80{ }^{\circ} \mathrm{C}$.

2. $1000 \times$ Heparin is made by diluting $1 \mathrm{mg} / \mathrm{ml}$ of Heparin (Sigma catalogue \# $\mathrm{H} 3393)$ in PBS. Make $1 \mathrm{ml}$ aliquots and store at $-80^{\circ} \mathrm{C}$.

\subsubsection{Derivation of Mouse TS Cells}

1. One or two days before day before blastocyst collection, plate Mitomycin C-treated MEFs in low-wall 4-well plates in a final volume of $0.5 \mathrm{ml}$ DMEM/10\%FBS per well.

2. On the day of blastocyst collection replace the DMEM/10\% FBS on the feeders with TS cell medium adding fresh FGF basic and FGF4 to the medium.

3. Sacri fi ce mated females using methods approved by your institution's animal use and care committee at a time that will allow the collection of late morula or early blastocyst stage embryos (Day 3.0 to Day 3.5 days post coitus).

4. Isolate blastocysts by dissection of the uterine horns and utilizing a $1 \mathrm{ml}$ syringe, M2 medium, and a 26 gauge needle to flush the embryos into a petri dish. Detailed protocols describing mouse blastocyst collection have been described elsewhere (20).

5. Wash the embryos through PBS-PVP and add a single embryo to each well of the 4-well plate containing the feeder MEFs.

6. Return the plates to a standard tissue culture incubator $\left(37^{\circ} \mathrm{C}, 5 \% \mathrm{CO}_{2}\right)$ and allow blastocyst outgrowths to form.

7. After 2 days of culture replace medium with fresh TS cell medium containing FGF basic and FGF4.

8. Plate a second group of mouse feeders on low-wall 4-well plates. 
9. After a 4 or 5 days of growth blastocyst outgrowths should be easily visible and have reached a size of greater than $750 \mu \mathrm{m}$. Do not let outgrowths become too large as the efficiency of stem cell isolation will rapidly begin to diminish (see Note 1).

10. Carefully aspirate the TS cell medium with a pipette and wash with PBS. The outgrowths will be very loosely attached, so take great care not to knock them loose.

11. To dissociate these structures add $0.1 \mathrm{ml} 0.1 \%$ trypsin/ $1 \mathrm{mM}$ EDTA and incubate for $5 \mathrm{~min}$ at $37^{\circ} \mathrm{C}$.

12. After incubation, use a $200 \mu$ pipette (set to a volume of $75 \mu \mathrm{l}$ ) to dissociate the outgrowths by pipetting up and down.

13. Add $600 \mu \mathrm{l}$ of Fesh TS cell medium containing fresh FGF basic and FGF4 to the dissociated outgrowths and transfer to a well in the new 4-well plates.

14. After $12 \mathrm{~h}$, replace medium with fresh TS cell medium (+ heparin, FGF basic, and FGF4).

15. Culture TS cells in the above medium in a standard tissue culture incubator $\left(37^{\circ} \mathrm{C}\right.$, $5 \% \mathrm{CO}_{2}$ incubator) replacing TS cell medium every 2 days. After approximately 1 week, TS cell colonies will begin to form. Often, XEN cells will also begin to grow. These cells tend to grow as single cells in clumps that begin to branch out. It is important to pick TS cell colonies before the plate becomes too overgrown so as to minimize the chance of XEN contamination (see Note 2) (Fig. 1).

16. Plate mouse feeders in either a flat-bottom 96 -well plate or 24 -well plate depending on the number of colonies.

17. Aspirate the medium from the 4-well plates and wash TS cell colonies twice with PBS.

18. After the last wash, cover the cells with $150 \mu \mathrm{l}$ of PBS.

19. Using a dissecting scope use a $20 \mu \mathrm{l}$ pipette to add approximately $10 \mu \mathrm{l}$ of $0.1 \%$ trypsin/1 mM EDTA directly onto the target colony, then mechanically break the colony away from the tissue culture surface, and pick up with the pipette.

20. Eject colony in a $0.5 \mathrm{ml}$ tube on a $37^{\circ} \mathrm{C}$ heating block.

21. After $\sim 5$ min add $100 \mu \mathrm{l}$ of fresh TS cell medium containing heparin, FGF basic, and FGF4.

22. Pipette up and down to dissociate the cells and transfer to a single well of the tissue culture plate containing the newly plated feeders.

23. After $12-24 \mathrm{~h}$ replace medium with fresh.

24. Culture TS cells in the above medium in a standard tissue culture incubator $\left(37^{\circ} \mathrm{C}\right.$, $5 \% \mathrm{CO}_{2}$ incubator) replacing TS cell medium every 2 days.

25. TS cells may now be cultured in the above medium in a standard tissue culture incubator $\left(37^{\circ} \mathrm{C}, 5 \% \mathrm{CO}_{2}\right.$ incubator). Cells are typically passaged (1:20) every $2-$ 
3 days. If they are split 1:20, they may become confluent in $2-3$ days. TS cell media is changed every second day; however, when they reach $>60 \%$ confluence, the media should be changed daily.

\subsection{Maintenance and Passage of TS Cells}

1. To passage TS cells wash twice with PBS, and dissociate colonies with enough $0.1 \%$ trypsin/ $1 \mathrm{mM}$ EDTA to cover the bottom of the plate.

2. Cells should begin to lift off the plate after $\sim 1-2$ min at which point colonies should be dissociated by gentle pipetting up and down.

3. Add TS cell medium containing heparin, FGF basic, and FGF4 to stop the reaction. Split cells 1:20 and transfer into a new well of feeder cells.

4. After $12 \mathrm{~h}$ replace the medium on the newly plated cells with fresh TS cell medium containing heparin, FGF basic, and FGF4.

\subsection{Culture and Passage of TS Cells in the Absence of Feeders}

In certain experimental situations it is necessary to culture TS cells in the absence of MEFfeeders. For example, when diagnosing imprinted gene expression it is best not to have feeder lines contributing to the analysis. To this end, TS cells may be grown in gelatintreated plastic (see Note 3).

MEFs and differentiated trophoblast cells adhere to the tissue culture dish more quickly than TS cells. This differential plating time can be used to recover floating TS cells in the medium after the MEFs and other cell types have adhered to the tissue culture plastic. TS cells can be maintained in the absence of MMC-MEFs in medium supplemented with 70\% MEF-conditioned medium. The example below is for a 100-mm cell culture dish. Adjust volumes accordingly for different sizes of dishes or flasks.

\subsubsection{Production of MEF-Feeder-Conditioned Medium}

1. Thaw a frozen vial of Mitomycin-C-treated MEFs in a $37{ }^{\circ} \mathrm{C}$ water bath, transfer entire contents into a $1.5-\mathrm{ml}$ tube, and centrifuge at $400 \times g$ for $4 \mathrm{~min}$.

2. Remove the supernatant and gently resuspend the cells in $1 \mathrm{ml}$ of DMEM/10\% FBS.

3. Transfer cells into a $15 \mathrm{~cm}$ dish containing $25 \mathrm{ml}$ DMEM/10\% FBS.

4. Culture cells at $37{ }^{\circ} \mathrm{C}$ for $24-48 \mathrm{~h}$ to let cells settle.

5. Replace medium with $25 \mathrm{ml} \mathrm{TS}$ cell medium that does not contain heparin, FGF basic, and FGF4.

6. Incubate cells in a standard tissue culture incubator $\left(37^{\circ} \mathrm{C}, 5 \% \mathrm{CO}_{2}\right.$ incubator) for 3 days.

7. On the third day pre-wet a $0.45 \mu \mathrm{m}$ syringe filer with fresh TS cell medium that does not contain FGF basic and FGF4. 
8. Draw the medium on the $15 \mathrm{~cm}$ plate up into the $15 \mathrm{ml}$ syringe.

9. Filter medium into a $50 \mathrm{ml}$ conical tube. It may take a few pulls from each plate.

10. The medium is now feeder conditioned and may be stored at $-80{ }^{\circ} \mathrm{C}$.

11. Replace aspirated medium with a second $25 \mathrm{ml}$ volume of TS cell medium that does not contain heparin, FGF basic, and FGF4.

12. A second collection of filtered medium is possible by repeating steps 5-10.

\subsubsection{Culture of TS Cells in MEF-Feeder-Conditioned Medium}

1. Grow TS cells on MEF-Feeders as described above.

2. Two to $3 \mathrm{~h}$ before passaging the cells, the tissue culture dishes that will be used to culture the MEF-feeder-free TS cells need to be treated with $1 \%$ Gelatin. Add enough $1 \%$ Gelatin in PBS to completely cover the bottom of the tissue culture well and place in a standard tissue culture incubator for $2-3 \mathrm{~h}$.

3. Wash TS cells twice with PBS, and dissociate colonies with enough $0.1 \%$ trypsin/1 mM EDTA to cover the bottom of the plate.

4. Cells should begin to lift off the plate after $\sim 1-2$ min at which point colonies should be dissociated by gentle pipetting up and down.

5. Add conditioned TS cell medium containing FGF basic and FGF4 to stop the reaction.

6. Transfer the cells to a new tissue culture plate and allow feeder cells to settle our for $1 \mathrm{~h}$.

7. After $1 \mathrm{~h}$ a large proportion of the MEF-feeders will have attached to the tissue culture dish. Pick up the remaining cells and place in a suitable tube. Discard the tissue culture well/dish with the attached feeders.

8. Remove the $1 \%$ gelatin solution from the tissue culture plates and split the TS cells 1:7.5 or 1:10 and transfer into a well of the gelatin-coated dish.

9. After $12 \mathrm{~h}$ replace the medium on the newly plated cells with fresh conditioned TS cell medium containing heparin, FGF basic, and FGF4.

10. Cells may be passaged in conditioned TS cell medium containing FGF basic and FGF4 as described above.

\subsection{Freezing TS Cell Cultures}

1. Prepare the TS Cell Freezing Medium by combining the components listed above. Place Medium on ice.

2. Wash con fl uent TS cell cultures twice with PBS, and dissociate colonies with enough $0.1 \%$ trypsin/ $1 \mathrm{mM}$ EDTA to cover the bottom of the plate.

3. Cells should begin to lift off the plate after $\sim 1-2$ min at which point colonies should be dissociated by gentle pipetting up and down. 
4. Add TS cell medium containing FGF basic and FGF4 to stop the reaction.

5. Remove an aliquot of cells to passage as necessary.

6. Transfer the remaining cells to a $1.5 \mathrm{ml}$ tube and spin at $4,000 \times g$ for $4 \mathrm{~min}$.

7. Remove media and resuspend cells in $1 \mathrm{ml}$ of TS cell freezing medium.

8. Transfer cells to a $15 \mathrm{ml}$ tube containing $4 \mathrm{ml}$ of TS Cell Freezing Medium.

9. Mix the cells by inversion and aliquot the cells in $1 \mathrm{ml}$ volumes into five cryovials.

10. Place cells in cell freezer and place in the $-80{ }^{\circ} \mathrm{C}$ freezer overnight.

11. The next day transfer frozen cells to either liquid nitrogen or $-160{ }^{\circ} \mathrm{C}$ freezer for long-term storage (see Note 4).

\section{Notes}

1. TS cells are a challenging cell type to derive and maintain in culture. TS cells grow very slowly when plated at low density but upon reaching a critical mass begin to grow very quickly. This property is likely due to an as yet unidentified secreted factor. Given these observations we have always found that derivation of TS cells is more efficient when multiple blastocysts are plated and dissociated in a single culture dish. Once multiple TS cell colonies begin to emerge clonal populations are picked.

2. When deriving TS cells, care must be taken not to allow XEN stem cells to take over the culture dish. In contrast to the smooth morphology of TS cell colonies, XEN cells grow in clumps of individual cells but will quickly spread throughout the dish.

3. TS cells typically take a long time to recover after being frozen. Be sure to plate a large number of cells in a dish to ensure a rapid recovery. Furthermore, after freezing a significant number of cells will spontaneously begin to differentiate. Allow two to three passages for the stem cell population to stabilize before proceeding with your experiments.

4. Culture of TS cells in the absence of feeders is very challenging. A significant number of TS cell colonies will have subpopulations that may differentiate when plated on plastic or glass. Again, allow cells to passage two to three times in conditioned medium before beginning experiments.

\section{Acknowledgments}

This work was supported by the NIH grant AA020129-02.

\section{References}

1. Verona RI, Mann MR, Bartolomei MS. Genomic imprinting: intricacies of epigenetic regulation in clusters. Annu Rev Cell Dev Biol. 2003; 19:237-259. [PubMed: 14570570]

2. Odom LN, Segars J. Imprinting disorders and assisted reproductive technology. Curr Opin Endocrinol Diabetes Obes. 2010; 17:517-522. [PubMed: 20962636] 
3. Uribe-Lewis S, Woodfine K, Stojic L, Murrell A. Molecular mechanisms of genomic imprinting and clinical implications for cancer. Expert Rev Mol Med. 2011; 13:e2. [PubMed: 21262060]

4. Eggan K, Akutsu H, Hochedlinger K, Rideout W, Yanagimachi R, Jaenisch R. X-Chromosome inactivation in cloned mouse embryos. Science. 2000; 290:1578-1581. [PubMed: 11090356]

5. Hill JR, Burghardt RC, Jones K, Long CR, Looney CR, et al. Evidence for placental abnormality as the major cause of mortality in first-trimester somatic cell cloned bovine fetuses. Biol Reprod. 2000; 63:1787-1794. [PubMed: 11090450]

6. Bourc'his D, Le Bourhis D, Patin D, Niveleau A, Comizzoli P, et al. Delayed and incomplete reprogramming of chromosome methylation patterns in bovine cloned embryos. Curr Biol. 2001; 11:1542-1546. [PubMed: 11591324]

7. Xue F, Tian XC, Du F, Kubota C, Taneja M, et al. Aberrant patterns of X chromosome inactivation in bovine clones. Nat Genet. 2002; 31:216-220. [PubMed: 12032569]

8. Santos F, Zakhartchenko V, Stojkovic M, Peters A, Jenuwein T, et al. Epigenetic marking correlates with developmental potential in cloned bovine preimplantation embryos. Curr Biol. 2003; 13:11161121. [PubMed: 12842010]

9. Mann MR, Lee SS, Doherty AS, Verona RI, Nolen LD, et al. Selective loss of imprinting in the placenta following preimplantation development in culture. Development. 2004; 131:3727-3735. [PubMed: 15240554]

10. Lin J, Shi L, Zhang M, Yang H, Qin Y, et al. Defects in trophoblast cell lineage account for the impaired in vivo development of cloned embryos generated by somatic nuclear transfer. Cell Stem Cell. 2011; 8:371-375. [PubMed: 21474101]

11. Martin GR. Isolation of a pluripotent cell line from early mouse embryos cultured in medium conditioned by teratocarcinoma stem cells. Proc Natl Acad Sci U S A. 1981; 78:7634-7638. [PubMed: 6950406]

12. Nagy A, Rossant J, Nagy R, Abramow-Newerly W, Roder JC. Derivation of completely cell culture-derived mice from early-passage embryonic stem cells. Proc Natl Acad Sci U S A. 1993; 90:8424-8428. [PubMed: 8378314]

13. Tanaka S, Kunath T, Hadjantonakis AK, Nagy A, Rossant J. Promotion of trophoblast stem cell proliferation by FGF4. Science. 1998; 282:2072-2075. [PubMed: 9851926]

14. Kunath T, Arnaud D, Uy GD, Okamoto I, Chureau C, et al. Imprinted X-inactivation in extraembryonic endoderm cell lines from mouse blastocysts. Development. 2005; 132:1649-1661. [PubMed: 15753215]

15. Lewis A, Mitsuya K, Umlauf D, Smith P, Dean W, et al. Imprinting on distal chromosome 7 in the placenta involves repressive histone methylation independent of DNA methylation. Nat Genet. 2004; 36:1291-1295. [PubMed: 15516931]

16. Terranova R, Yokobayashi S, Stadler MB, Otte AP, van Lohuizen M, et al. Polycomb group proteins Ezh2 and Rnf2 direct genomic contraction and imprinted repression in early mouse embryos. Dev Cell. 2008; 15:668-679. [PubMed: 18848501]

17. Latos PA, Stricker SH, Steenpass L, Pauler FM, Huang R, et al. An in vitro ES cell imprinting model shows that imprinted expression of the Igf $2 \mathrm{r}$ gene arises from an allele-specific expression bias. Development. 2009; 136:437-448. [PubMed: 19141673]

18. Market-Velker BA, Zhang L, Magri LS, Bonvissuto AC, Mann MR. Dual effects of superovulation: loss of maternal and paternal imprinted methylation in a dose-dependent manner. Hum Mol Genet. 2010; 19:36-51. [PubMed: 19805400]

19. Erlebacher A, Price KA, Glimcher LH. Maintenance of mouse trophoblast stem cell proliferation by TGF-beta/activin. Dev Biol. 2004; 275:158-169. [PubMed: 15464579]

20. Nagy, A. Manipulating the mouse embryo: a laboratory manual. CSHL Press; Cold Spring Harbor, NY: 2003. 

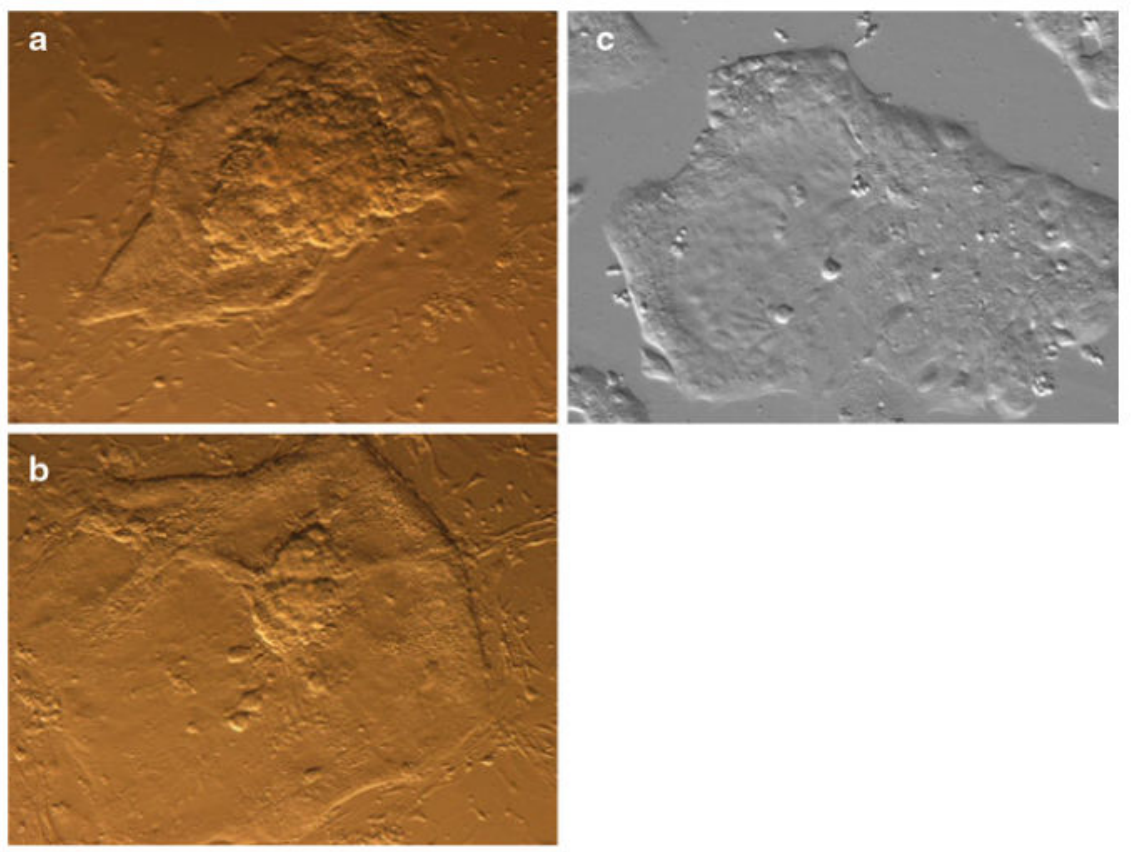

Fig. 1.

Light micrographs depicting sequential stages in the isolation and culture of trophectoderm stem cells. (a) Early passage TS cells 4-6 days after dissociation of the initial embryonic body. Note the "smooth" cells along the expanding margins and "rough" cells in the center. (b) TS cells after the third passage Colonies at this point will be primarily composed of "smooth" cells growing in individual colonies. (c) TS cells after ten passages in culture growing on gelatin-coated plastic, in conditioned medium. Cells grow in relatively homogenous colonies with actively proliferating, expanding margins of smooth cells. The colonies shown here are confluent and need to be split within $12 \mathrm{~h}$. 